\title{
PENGARUH PENGGUNAAN SEDIAAN FIXED DOSE COMBINATION (FDC) DIBANDINGKAN DENGAN TABLET LEPAS OBAT ANTI-TUBERKULOSIS TERHADAP PENINGKATAN NILAI SGPT DAN SGOT PADA PASIEN TUBERKULOSIS DI BALAI BESAR KESEHATAN PARU MASYARAKAT MAKASSAR
}

\author{
Munawarah $^{1}$, M. Natsir Djide ${ }^{1}$, Arif Santoso ${ }^{2}$, Elly Wahyuddin ${ }^{1}$, Sartini ${ }^{1}$, Yulia Yusrini Djabir ${ }^{1}$ \\ ${ }^{1}$ Fakultas Farmasi, Universitas Hasanuddin, Makassar \\ ${ }^{2}$ Departemen Ilmu Penyakit Dalam, Fakultas Kedokteran, Universitas Hasanuddin, Makassar
}

Kata Kunci :

Sediaan Fixed Dose Combination, Tablet lepas OAT,

Tuberkulosis, Kadar SGPT, Kadar SGOT

\begin{abstract}
ABSTRAK
Penelitian ini bertujuan untuk menganalisis pengaruh pemberian terapi Fixed Dose Combinaton (FDC) dibandingkan dengan tablet lepas Obat Anti Tuberkulosis (OAT) terhadap resiko terjadinya Drug Induced Hepatotoxicity (DIH) yang ditandai dengan peningkatan nilai SGPT dan SGOT pada penderita Tuberkulosis. Desain penelitian yang digunakan adalah penelitian observasional non eksperimen dengan rancangan deskriptif-analitik. Pengambilan sampel dilakukan dengan teknik non-probability sampling dengan cara consecutive sampling. Jumlah sampel 30 pasien, terdiri dari kelompok FDC dan kelompok tablet lepas jumlah masing-masing 17 dan 13 sampel. Dianalisis dengan uji statistik metode MannWhitney U. Hasil penelitian menunjukkan bahwa selisih nilai SGPT dan SGOT antara kelompok FDC dan kelompok tablet lepas menunjukkan perbedaan yang signifikan $(\mathrm{p}>0,05)$.
\end{abstract}

\section{PENDAHULUAN}

Tuberkulosis (TB) tetap menjadi pembunuh menular terkemuka di seluruh dunia. TB disebabkan oleh Mycobacterium tuberculosis, yang dapat menghasilkan infeksi diam, laten atau penyakit aktif yang progresif. Jika diobati dengan tidak benar, TB menye babkan kerusakan jaringan progresif dan akhirnya, kematian. Karena upaya kesehatan masyarakat yang mulai diperbaharui, tingkat TB di Amerika Serikat terus menurun. Sebaliknya, TB tetap tidak terkendali di banyak negara berkembang sampai pada titik di mana sepertiga populasi dunia saat ini terinfeksi (Dipiro, 2013). Indonesia memiliki jumlah kasus TB terbesar ke-dua di dunia. Ada satu pasien tuberkulosis baru setiap menit di Indonesia, ada 2 kasus baru positif BTA setiap dua menit dan ada satu kematian akibat tuberkulosis terjadi di Indonesia setiap 4 menit (1).

Merujuk pada angka kejadian yang tinggi, Indonesia bekerjasama dengan World Health Organization (WHO) menggalang strategi penanggulangan TB di Indonesia yang kemudian disebut strategi Directly Observed Treatment Short Course (DOTS) (DJPPM, 1999). Salah satu programnya adalah melaksanakan pengobatan tuberkulosis dengan Obat Anti Tuberkulosis (OAT). Pengobatan tuberkulosis terbagi menjadi dua fase, yakni fase intensif (2-3 bulan) dan fase lanjutan (4 atau 7 bulan) (PDPI, 2006). Sebagian besar negara yang menggunakan strategi DOTS telah mengganti tablet lepas rifampicin dan isoniazid dengan tablet kombinasi. The World
Health Organization (WHO) and the International Union Against Tuberkulosis and Lung Disease (IUATLD/The Union) mendukung penggunaan formulasi FDC untuk pengobatan TB paru pada tahun 1994 (2).

Pada tahun 1997 kekhawatiran tentang bioavailabilitas rifampisin karena ketersediaan hayati yang relatif sedikit ketika dikombinasikan dengan isoniazid serta paket blister FDC yang tidak stabil dan tingkat penyerapan yang lemah menyebabkan WHO dan IUATLD untuk mengeluarkan pedoman lebih lanjut untuk memastikan ketersediaan hayati setiap kompoonen obat dari formulasi FDC dalam mengurangi kegagalan pengobatan, meningkatkan kepatuhan pasien, kekambuhan penyakit dan reistensi obat (3).

Formulasi kombinasi dosis tetap yang menyederhanakan pemberian obat-obatan dan mencegah perkembangan resistensi obat telah direkomendasikan sebagai rejimen pengobatan standar tuberkulosis. Namun rekomendasi komposisi dan dosis pada FDC berbeda dengan tablet lepas. Pertanyaan tentang keefektifan dan resiko efek samping dari formulasi FDC dianggap penting sehingga dibutuhkan sebuah studi untuk membandingkan kedua bentuk pengobatan dan mengetahui pengaruhnya terhadap resiko terjadinya efek samping yang ditimbulkan selama penggunaan obat-obat antituberkulosis. 


\section{METODE PENELITIAN}

\section{Rancangan Penelitian}

Jenis penelitian ini merupakan penelitian observasional non experiment consecutive sampling, dengan mengikuti rancangan deskriptif analitik (kohort study) dan pengambilan data secara prospektif.

\section{Lokasi dan Waktu Penelitian}

Penelitian ini dilakukan pada bulan April - September $2018 \mathrm{di}$ Balai Besar Kesehatan Paru Mayarakat Makassar (BKKBM).

\section{Bahan Penelitian}

Bahan yang digunakan adalah data rekam medik pasien lengkap (data laboratorium, kadar SGPT dan SGOT)

\section{Prosedur Kerja}

Pasien tuberkulosis yang dirawat di Balai Besar Kesehatan Paru Masyarakat Makassar (BBKPM) dengan Kriteria inklusi laki-laki atau perempuan dengan usia $>12$ tahun. Pasien penderita TB yang diterapi FDC OAT dan tablet lepas OAT kategori 1 fase intensif. Kriteria eksklusi pasien penderita TB yang diterapi OAT mengalami penyakit hati dari awal pengobatan. Pasien TB paru yang mendapatkan terapi OAT kategori 2. Subyek diamati dan dicatat hasil pengamatan sampai 2 bulan pengobatan.

\section{Analisis dan Penyajian Data}

Analisis data dalam penelitian ini dilakukan dengan cara analisis deskriptif dari data hasil penelitian mengenai karakteristik subyek disajikan dalam bentuk narasi dan tabel. Data yang diperoleh dilakukan analisis dengan pengolahan data secara statistik menggunakan metode Mann-Whitney U untuk mengetahui perubahan parameter Kadar SGPT dan SGOT sebelum dan setelah terapi

\section{HASIL DAN PEMBAHASAN}

Subjek penelitian terdiri dari subjek laki-laki 15 0rang (50\%) dan perempuan 15 orang (50\%). Jumlah laki-laki dan perempuan yang menderita tuberkulosis jumlahnya sama. Tidak ditemukannya hubungan antara jenis kelamin dengan kejadian TB karena proporsi penderita TB pada laki-laki dan perempuan berdasarkan Riskesdas 2013 hampir sama, meskipun ditemukan perbedaan jumlah penderita TB pada laki laki dan perempuan. Hal ini kemungkinan disebabkan oleh faktor lain seperti perbedaan perilaku dimana lebih banyak laki laki yang merokok (96,3\%) dibandingkan dengan perempuan $(3,7 \%)(4)$.

Kelompok usia responden yang dominan yaitu pada interval umur 19-25 tahun yaitu berjumlah 10 orang (33,3\%), dan pada rentang umur 27-34 tahun sebanyak 6 orang $(20,0 \%)$. Menurut penelitian sebelumnya, tuberkulosis paling sering terjadi pada orang berusia 25 sampai 44 tahun (35\% dari semua kasus di AS pada tahun 2002), diikuti oleh usia 45 sampai 64 tahun (28\%) dan 65 tahun dan lebih tua (21\%) (5). Di Negara berkembang sendiri, $75 \%$ penderita tuberkulosis ditemukan pada usia produktif 15-49 tahun (4).

Pada penelitian ini pasien yang memenuhi kriteria inklusi dari kelompok FDC dan kelompok tablet lepas masingmasing 17 dan 13 orang. Hasil uji non parametrik MannWhitney U menunjukkan pada kelompok FDC pemeriksaan SGPT dan SGOT pada pra-treatment ke post-treatment masing-masing dengan peningkatan rata-rata 7,88 $\pm 18,587$ dan 19,94 $\pm 5,273$ dengan p-value masing-masing 0,012 dan $0,022(\mathrm{p}<0,05)$. Pada kelompok Tablet lepas pemeriksaan SGPT dan SGOT, masing-masing dengan peningkatan ratarata sebesar $109,692 \pm 199,777$ dan $114,769 \pm 190,251$ dengan $\mathrm{p}$-value masing-masing 0,005 $(\mathrm{p}<0,05)$ sehingga dapat disimpulkan bahwa terdapat peningkatan yang signifikan kadar SGPT dan SGOT pada kedua kelompok.

Untuk perbandingan selisih nilai SGPT pada pra-treatment ke post-treatment antara kedua kelompok didapatkan kelompok FDC rata-rata 7,88 $\pm 18,587$ dan pada kelompok tablet lepas dengan rata-rata 109,692 $\pm 199,777$, nilai $p=0,017(p>0,050)$, jadi dapat disimpulkan bahwa terdapat perbedaan signifikan antara peningkatan kadar SGPT antara kelompok FDC dan kelompok tablet lepas.

Selisih nilai SGOT pada pra-treatment ke post-treatment pada kelompok FDC meningkat rata-rata 5,47 $\pm 12,354$ sedangkan pada kelompok tablet bebas meningkat rata-rata sebesar $114,769 \pm 190,251$. Nilai $p=0,027(p<0,05)$ yang artinya terdapat perbedaan signifikan. Hal ini menunjukkan bahwa untuk peningkatan kadar SGOT pra-treatment ke posttreatment terdapat perbedaan nilai yang nyata antara kelompok FDC dan tablet lepas.

\begin{tabular}{|c|c|c|c|c|c|}
\hline \multirow{2}{*}{ SGPT } & \multicolumn{2}{|c|}{ FDC } & \multicolumn{2}{|c|}{ Tablet Lepas } & \multirow{2}{*}{ Nilai $\mathbf{P}$} \\
\hline & Rerata & SD & Rerata & SD & \\
\hline $\begin{array}{c}\text { Pre- } \\
\text { treatment } \\
\text { (0 bulan) }\end{array}$ & 21,24 & 16,037 & 20,38 & 8,959 & 0,659 \\
\hline $\begin{array}{l}\text { Post- } \\
\text { treatment } \\
\text { ( } 2 \text { bulan) }\end{array}$ & 29,12 & 21,650 & 130,08 & 205,240 & 0,238 \\
\hline Selisih & 7,88 & 18,587 & 109,692 & 199,777 & 0,017 \\
\hline
\end{tabular}

Tabel 2. Perbedaan kadar SGOT pada pasien tuberkulosis antara kelompok FDC dan kelompok tablet lepas OAT

\begin{tabular}{|c|c|c|c|c|c|}
\hline \multirow{2}{*}{ SGOT } & \multicolumn{2}{|c|}{ FDC } & \multicolumn{2}{|c|}{ Tablet Lepas } & \multirow{2}{*}{$\begin{array}{c}\text { Nilai } \\
\mathbf{P}\end{array}$} \\
\hline & Rerata & SD & Rerata & SD & \\
\hline $\begin{array}{l}\text { Pre- } \\
\text { treatment } \\
\text { ( } 0 \text { bulan) }\end{array}$ & 19,94 & 5,273 & 20,54 & 6,346 & 0,966 \\
\hline $\begin{array}{l}\text { Post } \\
\text { treatment } \\
\text { ( } 2 \text { bulan) }\end{array}$ & 25,41 & 13,286 & 135,31 & 193,919 & 0,056 \\
\hline Selisih & 5,47 & 12,354 & 115,769 & 190,251 & 0,027 \\
\hline
\end{tabular}

Dari hasil analisis perbandingan kedua kelompok, kelompok yang menggunakan tablet lepas memberikan pengaruh lebih besar terhadap resiko terjadinya hepatotoksisitas. Hal ini sesuai dengan penelitian yang dilakukan oleh Michael Borek, MD, Head of Clinical Development \& Medical Affairs (2007) yang membandingkan penggunaan terapi FDC dan tablet lepas di berbagai negara dan mendapatkan $16,3 \%$ pasien dengan terapi tablet lepas mengalami reaksi efek samping yang berdampak pada liver dan system billiary sedangkan pada pasien yang menggunakan FDC hanya 8,5\% yang mengalami reaksi efek samping (7).

Hampir semua OAT mempunyai efek hepatotoksik kecuali streptomisin. Kerusakan sel hati bervariasi dari yang ringan asimptomatik sampai menimbulkan gejala serius akibat nekrosis sel hati. Pirazinamid yang sering dipakai untuk pengobatan jangka pendek Tb paru telah dilaporkan menyebabkan hepatitis. Peningkatan SGOT dan SGPT merupakan gejala dini dari kelainan hati. (8).

\section{KESIMPULAN}

Berdasarkan hasil penelitian, pemberian sediaan Fixed Dose Combination (FDC) dibandingkan dengan pemberian tablet lepas Obat Antituberkulosis dapat disimpulkan bahwa pasien 
yang mendapatkan terapi tablet lepas OAT cenderung memiliki efek yang lebih besar untuk meningkatkan nilai SGPT dan SGOT dan beresiko menyebabkan Drug Induced Hepatotoxicity (DIH).

\section{DAFTAR PUSTAKA}

1. World Health Organization. 2017. The 4 drugs fixed-dose combination tablet recommended by WHO for treating tuberculosis. Geneva : World Health Organization : $2-10$.

2. Bartacek A,Schutt D ,Panosch B, Borek M, et al. 2009. Comparison of a four-drug fixed - dose combination regimen with a single tablet regimen in smear-positive pulmonary tuberculosis. Int JTuberc Lung Dis; 13(6):760-6.PMID:19460254T

3. Blumberg HM, Burman WJ, Chaisson RE, Daley CL, Etkind SC, Friedman LN, et al. 2003. American Thoracic Society/Centers for Disease Control and Prevention/Infectious Diseases Society of America: Treatment of tuberculosis. Am J Respir Crit Care Med. 167((4)):60362. http://dx.doi.org/10.1164/rccm.167.4.603

4. Made Agus Nurjana. 2015. Faktor Resiko Terjadinya Tuberkulosis Paru Usia Produktif(15-49 Tahun) Di Indonesia. Media Litbangkes, Vol. 25 No. 3. Balai Litbang P2B2 Donggala, Badan Litbang Kesehatan, Kemenkes RI. Donggala, Indonesia. $165-170$

5. Dipiro, T. J., Talbert, C. R., Gary, Y. E., dan Wells, B. G. 2013. Pharmacotherapy A Phatofisiologi Approach. Sixth Edition. New York: The Macgraw Hill Companies.Wardhani RA. Patogenesis, 2013. Diagnosis dan klasifikasi Tubercolosis. www.staff.ui.ac/ system/files/user/retno.asti/material/.)

6. Michael B. 2007. Rimstar®: Pharmacokinetics and Clinical Trial Results. Münchenwiler.

7. Departemen Kesehatan RI. 2008. Pedoman nasional penanggulangan tuberkulosis. 2nd Edition. Jakarta: Departemen Kesehatan RI. 